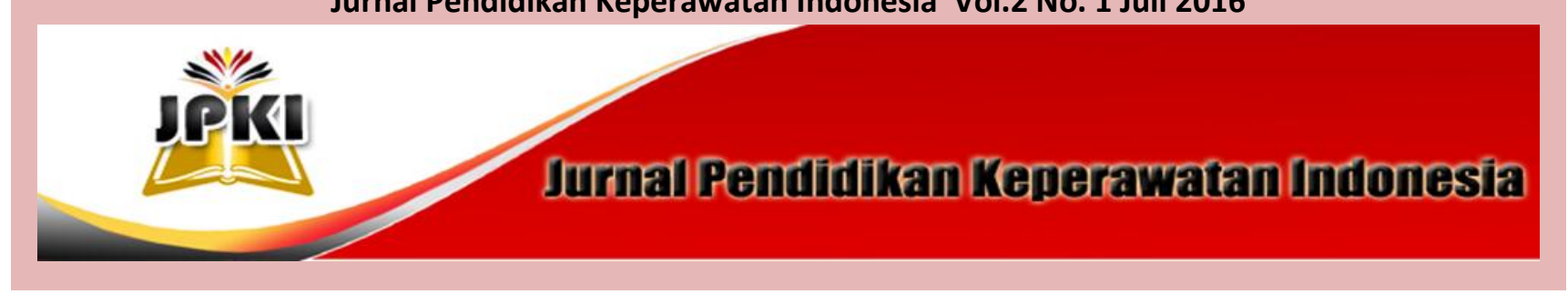

Journal homepage : http://ejournal.upi.edu/index.php/JPKI

\title{
PENGARUH MUSIK ANGKLUNG TERHADAP KUALITAS HIDUP WANITA LANJUT USIA
}

\author{
Lilis Komariyah \\ Fakultas Pendidikan Olahraga dan Kesehatan, Universitas Pendidikan Indonesia \\ Email : lilis.komariyah@yahoo.com
}

\begin{abstract}
ABSTRAK
Peningkatan derajat kesehatan menyebabkan bertambahnya usia harapan hidup yang memberikan dampak terhadap meningkatnya jumlah penduduk lanjut usia. Dengan meningkatnya usia harapan hidup maka sangat penting untuk memperbaiki kualitas hidup lansia. Musik angklung merupakan kearifan budaya lokal yang sedang berkembang saat ini. Adapun tujuan penelitian ini untuk menganalisis pengaruh musik angklung terhadap peningkatan kualitas hidup lansia yang tinggal di panti jompo. Metode penelitian yang digunakan adalah penelitian eksperimen dengan pre dan post test design without control. Subjek penelitian menggunakan purposive sampling sebanyak 15 orang wanita lansia berusia 60-90 tahun yang berasal dari Panti Sosial Tresna Werdha Budi Pertiwi. Penelitian ini menggunakan instrumen WHOQOL-BREFF. Data hasil penelitian dianalisis menggunakan uji normalitas Shapiro-Wilk, uji Kolmogorov Smirnov, dan uji ANOVA. Hasil penelitian menunjukkan bahwa wanita lansia yang mengikuti musik angklung memiliki peningkatan kualitas hidup secara bermakna pada domain fisik $(55,27 \pm 7,86$ vs $52,80 \pm 6,91)(\mathrm{p}<0,05)$, domain psikologis $(65,53 \pm 9,50$ vs $54,33 \pm 5,53)(\mathrm{p}<0,05)$, domain hubungan sosial $(71,07 \pm 8,76$ vs 57,67 $\pm 5,17)(\mathrm{p}<0,05)$, dan domain lingkungan $(61,40 \pm 5,15$ vs $56,33 \pm 4,67)(\mathrm{p}<0,05)$. Simpulan dari hasil penelitian ini didapatkan bahwa musik angklung dapat meningkatkan kualitas hidup wanita lansia pada domain fisik, psikologis, hubungan sosial, dan lingkungan. Adapun saran dari penelitian ini diharapkan bahwa musik angklung dapat diterapkan di seluruh unit lansia maupun panti jompo yang ada di Indonesia.
\end{abstract}

Kata kunci: wanita lansia, kualitas hidup, musik angklung

\section{ABSTRACT}

The enhancement of current health level and life expectancy provide implications to the number of elderly people in Indonesia. Health professionals, especially geriatric nurses, play an important role in increasing elderly life quality. One of the efforts is by practicing Brain Movement Exercise and Angklung music therapy. The aim of this study was to analysis the effect of brain movement exercise and angklung music on quality of life of elderly. The study design was an experimental pre and post design without control. The subjects were 15 healthy elderly woman age 60-90 years old whom came from a nursing home. The instrument research used was WHOQOL-BREF. Shapiro-Wilk test, Kolmogorov Smirnov, and ANOVA were used to analyze the data. The results showed that women elderly people who participated angklung music experienced a significant life quality improvement in physical domain $(55,27 \pm 7,86$ vs 52,80 $\pm 6,91)(p<0,05)$, psychological domain $(65,53 \pm 9,50 v s$ $54,33 \pm 5,53)(p<0,05)$, social relationship domain $(71,07 \pm 8,76$ vs 57,67 $\pm 5,17)(p<0,05)$, and environment domain $(61,40 \pm 5,15$ vs 56,33 $\pm 4,67)$ ( $p<0,05)$. In conclusion, angklung music can improve elderly womens life quality in physical, psychological, social relationship and environmental domains. Therefore, it is suggested that angklung music are implemented in all nursing house units in Indonesia.

Key words: elderly women, quality of life, angklung music 


\section{PENDAHULUAN}

Pelayanan kesehatan di Indonesia semakin membaik dengan salah satu indikator utama adalah meningkatnya derajat kesehatan masyarakat berupa meningkatnya usia harapan hidup, yaitu 67 tahun untuk laki-laki dan 71 tahun untuk perempuan (Darmojo, 2006). Peningkatan angka usia harapan hidup merupakan tanda positif dari keberhasilan pembangunan kesehatan, namun menempatkan Indonesia kedalam suatu masa pergeseran demografi yang mana struktur masyarakat Indonesia berubah dari masyarakat atau populasi muda pada tahun 1971 menjadi populasi yang lebih tua pada tahun 2020. Hal ini akan mengubah bentuk komposisi populasi penduduk Indonesia dari bentuk piramid menjadi bentuk bel (bell shape). Adapun yang dimaksud dengan lansia adalah sekelompok orang berusia di atas 60 tahun.

Seiring dengan bertambahnya jumlah lansia, terdapat banyak permasalahan yang dialami lansia di antaranya tidak berpendidikan, tidak memperoleh akses kesehatan, tidak memiliki jaminan hari tua, tidak memiliki dukungan sosial dari keluarga atau teman untuk merawat mereka, dan kurangnya latihan fisik. Banyak lansia yang pada akhirnya harus mengalami berbagai masalah psikis maupun fisik, seperti patologis pada kondisi fisik seperti terserang berbagai penyakit kronis dan kondisi psikis seperti stress, depresi, kesepian bahkan sampai nekad melakukan upaya bunuh diri (Salamah, 2005). Hal tersebut menyebabkan perubahan pada kualitas hidup mereka.

Kualitas hidup menurut World Health Organization (WHO) adalah persepsi seseorang dalam konteks budaya dan norma sesuai dengan tempat hidup orang tersebut berkaitan dengan tujuan, harapan, standar dan kepedulian selama hidupnya (WHO, 2009). Kualitas hidup seseorang merupakan fenomena yang multidimensional. WHO mengembangkan sebuah instrumen untuk mengukur kualitas hidup seseorang dari 4 aspek yaitu fisik, psikologis, sosial dan lingkungan. Betapa pentingnya berbagai dimensi tersebut tanpa melakukan evaluasi sulit untuk menentukan dimensi mana yang penting dari kualitas hidup seseorang.

Beberapa penelitian menunjukkan penurunan kualitas hidup lansia di karenakan terjadinya proses penyakit (fisiologis) pada lansia, seperti penurunan kualitas hidup pada lansia dengan stroke dan penyakit diabetes mellitus. Penelitian sebelumnya menemukan kualitas hidup lansia jika ditinjau dari aspek sosial dan lingkungan menunjukkan terdapat perbedaan yang bermakna antara lansia yang tinggal di panti jompo dengan lansia yang tinggal bersama keluarga.

Angklung sebagai salah satu kearifan budaya lokal, khususnya Jawa Barat merupakan alat musik yang ringan karena terbuat dari bambu. Selain itu, memiliki karakterisktik yaitu timbre yang khas, melatih kekompakan, kebersamaan, kenyamanan, kesenangan, dan bersifat rekreatif. Menurut Udjo (2011), Angklung dapat membangkitkan perhatian terhadap musik, menghidupkan musikalitas, dan mengembangkan rasa ritme, melodi harmoni, pengembangan intelegensi, dan kreativitas. Angklung dapat menjadi sarana penyaluran emosi, ekspresi untuk kebahagiaan dalam bermain musik, serta melatih koordinasi gerak tubuh saat mengikuti irama musik dalam rangka pengembangan syaraf psikomotorik. Bahkan saat ini, di beberapa pusat kesehatan telah ditemukan penelitian bahwa angklung dapat menjadi terapi penyembuhan yang berkaitan dengan pengembangan syaraf psikomotorik. Menurut Chandradewi (2013), musik angklung dapat menurunkan rasa kesepian pada lansia. Sedangkan penelitian mengenai pengaruh musik angklung terhadap kualitas hidup lansia belum pernah dilakukan.

\section{METODE PENELITIAN}

Metode penelitian yang digunakan adalah penelitian eksperimen dengan pre dan post test design without control. Subjek penelitian menggunakan purposive sampling sebanyak 15 orang wanita lansia berusia 60-90 tahun yang berasal dari Panti Sosial Tresna Werdha Budi Pertiwi. Variabel penelitian yang diukur adalah kualitas hidup lansia yang terdiri dari empat domain yaitu domain fisik, psikologis, hubungan sosial, dan lingkungan dengan menggunakan instrumen WHOQOLBREFF. Data hasil penelitian dianalisis menggunakan uji normalitas Shapiro-Wilk, uji Kolmogorov Smirnov, dan uji ANOVA. Penelitian ini dilakukan selama 4 minggu dengan frekuensi $2 \mathrm{x} /$ minggu pada bulan Juni 2015. 


\section{HASIL PENELITIAN}

Tabel 1. Distribusi Frekuensi dan Prosentase Berdasarkan Data Demografi Responden yang Mengikuti Musik Angklung (n=15)

\begin{tabular}{lcc}
\hline \multicolumn{1}{c}{ Data Demografi } & \multicolumn{2}{c}{ Kelompok B } \\
& $\begin{array}{c}\text { Terapi Angklung) } \\
\text { f }\end{array}$ & \% \\
\hline Usia & 10 & 66.7 \\
60-74 tahun & 5 & 33.3 \\
75-90 tahun & & \\
Pendidikan Terakhir & 1 & 6.7 \\
$\quad$ SD & 1 & 6.7 \\
SMP & 4 & 26.7 \\
SMA & 2 & 13.3 \\
Diploma & 7 & 46.7 \\
$\quad$ Tidak Sekolah & & \\
Status Perkawinan & 4 & 26.7 \\
$\quad$ Tidak Menikah & 11 & 73.3 \\
$\quad$ Janda & & \\
Penghasilan & 10 & 66.7 \\
$\quad$ < Rp.500.000 & - & 0 \\
$\quad$ Rp.500.000-1.0000.000 & 5 & 33.3 \\
$\quad$ > Rp. 1000.000 & 5 \\
\hline
\end{tabular}

Tabel 2. Pengaruh Musik Angklung terhadap Peningkatan Kualitas Hidup Wanita Lanjut Usia $(n=15)$

\begin{tabular}{lcccc}
\hline Domain & Tes & Mean & SD & Nilai p $^{*}$ \\
\hline Fisik & Pre & 52,80 & 6,91 & 0,000 \\
& Post & 55,27 & 7,86 & \\
Psikologis & Pre & 54,33 & 5,53 & 0,000 \\
& Post & 65,53 & 9,50 & \\
Hub.Sosial & Pre & 57,67 & 5,17 & 0,000 \\
& Post & 71,07 & 8,76 & \\
Lingkungan & Pre & 56,33 & 4,67 & 0,002 \\
& Post & 61,40 & 5,15 & \\
\hline
\end{tabular}

*) ANOVA

\section{PEMBAHASAN}

Dari penelitian yang dilakukan kepada 15 responden menunjukkan bahwa sebagian besar usia responden berada pada kelompok umur 60-74 tahun sebanyak 10 orang (66.7\%). Berdasarkan penelitian yang dilakukan Sutikno
(2011) menemukan, secara statistik faktor usia mempunyai hubungan yang signifikan dengan kualitas hidup. Lansia yang berumur 70 tahun ke atas memiliki kemungkinan untuk berkualitas hidup lebih buruk daripada lansia berusia kurang dari 70 tahun. Hal ini disebabkan karena dengan bertambahnya umur terdapat penurunan fisik, perubahan mental, perubahan psikososial dan perubahan dalam cara hidup. Berdasarkan pekerjaan seluruh wanita lansia di PSTW Budi Pertiwi tidak bekerja. Berdasarkan penghasilan sebagian besar wanita lansia berpenghasilan $<$ Rp.500.000 sebesar 66.7\%. Berdasarkan status pernikahan hampir seluruh wanita lansia 73.3\% berstatus janda. Menurut Wahl dkk, dalam Ritonga (2013) menemukan bahwa baik pada pria maupun wanita, individu dengan status menikah atau kohabitasi memiliki kualitas hidup yang lebih tinggi.

Berdasarkan pendidikan terakhir wanita lansia sebagian besar berpendidikan SD (46.7\%). Moons, dkk dalam Nofitri (2009), mengatakan bahwa tingkat pendidikan adalah salah satu faktor yang dapat memengaruhi kualitas hidup subjektif. Penelitian yang dilakukan oleh Wahl, dkk dalam Nofitri (2009) menemukan bahwa kualitas hidup akan meningkat seiring dengan lebih tingginya tingkat pendidikan yang didapatkan oleh individu. Hal ini sesuai dengan penelitian Purnama (2013), yang menyatakan bahwa semakin tinggi tingkat pendidikan membuat lansia semakin paham dan mengerti akan berbagai permasalahan yang dapat mengganggu kualitas hidupnya dan bagaimana menanganinya baik untuk dirinya sendiri atau lingkungan sekitar. Menurut Setyoadi (2011) bahwa tingkat pendidikan akan berdampak pada jenis pekerjaan, tingkat pendapatan lansia, dan bagaimana manajemen keuangan lansia di masa tuanya. Artinya bahwa, rata-rata kualitas hidup pada lansia bersifat subjektif tetapi dipengaruhi oleh tingkat pendidikan, pekerjaan dan penghasilan.

Dari hasil penelitian kualitas hidup wanita lansia yang mengikuti musik angklung memiliki peningkatan kualitas hidup secara bermakna pada domain fisik $(55,27 \pm 7,86$ vs $52,80 \pm 6,91)(\mathrm{p}<0,05)$, psikologis $(65,53 \pm$ $9,50$ vs $54,33 \pm 5,53) \quad(\mathrm{p}<0,05)$, domain 
hubungan sosial $(71,07 \pm 8,76$ vs $57,67 \pm 5,17)$ ( $\mathrm{p}<0,05)$, dan domain lingkungan $(61,40 \pm$ $5,15$ vs $56,33 \pm 4,67)(\mathrm{p}<0,05)$.

Dari hasil penelitian pada domain fisik terdapat peningkatan kualitas hidup secara bermakna pada lansia yang mengikuti musik angklung $(55,27 \pm 7,86$ vs $52,80 \pm 6,91)$ $(\mathrm{p}<0,05)$. Domain fisik meliputi nyeri dan ketidaknyamanan, tenaga dan lelah, tidur dan istrahat. Menurut Sacks (2011), musik secara langsung bisa mempengaruhi kerja otot kita. Musik mampu memengaruhi sistem dalam tubuh kita, termasuk hormon-hormon dalam tubuh. Musik mampu memengaruhi denyut jantung dan tekanan darah dengan merangsang hormon adrenalin. Bahkan saat ini, di beberapa pusat kesehatan telah ditemukan penelitian bahwa angklung dapat menjadi terapi penyembuhan yang berkaitan dengan pengembangan syaraf psikomotorik. Alat musik angklung lebih ringan, mudah, dan sederhana karena hanya menggerakan tangan untuk satu tangga nada, tapi dapat melatih lebih dari satu saraf dari organ tubuh untuk saling berintegrasi (Hermawan, 2011). Ketika mengambil suatu tangga nada, sudah melatih saraf motorik (melatih gerak tangan). Ketika melihat teks lagu untuk mengeluarkan katakata dan irama lagu, akan melatih mata menjadi aktif. Bahkan, telinga ikut bereaksi aktif karena lansia mendengar suaranya sendiri. Selain itu, lansia yang menyanyi akan memperbaiki gangguan berbahasa karena menyanyi bisa melatih kemampuan bicara. Jadi dengan bermain angklung, banyak organ tubuh yang dilibatkan sehingga domain fisik meningkat.

Domain psikologis meliputi aspek perasaan positif, berpikir, belajar, ingatan dan konsentrasi, harga diri, gambaran diri dan penampilan, dan perasaan negatif. Pada wanita lansia yang mengikuti musik angklung pada domain psikologis menunjukkan peningkatan kualitas hidup secara bermakna $(65,53 \pm 9,50$ vs $54,33 \pm 5,53)(\mathrm{p}<0,05)$. Hasil penelitian Ariani (2012) dengan menggunakan metode quasi eksperimen dengan jumlah sampel sebanyak 25 orang melalui purposive sampling menunjukkan terdapat perbedaan rasa kesepian yang bermakna sebelum dan sesudah dilakukan terapi musik angklung. Musik adalah bahasa jiwa, musik mampu membawa perasaan kearah mana saja. Musik yang didengar akan merangsang sistem saraf yang akan menghasilkan suatu perasaan.

Pada domain hubungan sosial meliputi aspek hubungan perorangan, dukungan sosial dan aktifitas seksual menunjukkan peningkatan yang bermakna $(71,07 \pm 8,76$ vs $57,67 \pm 5,17)$ $(\mathrm{p}<0,05)$. Hal ini kemungkinan disebabkan terapi musik angklung yang dilakukan secara bersama-sama dapat meningkatkan kemampuan komunikasi, kemampuan sosialisasi, rasa percaya diri, semangat hidup, dan peningkatan penghargaan terhadap diri sendiri bahwa diri mereka masih mampu melakukannya, masih mampu untuk berkarya dan menunjukan keterampilan mereka (Arisanti, 2010).

Pada domain lingkungan yang meliputi aspek keamanan fisik, lingkungan rumah, sumber penghasilan, kesehatan dan perhatian sosial, kesempatan untuk memperoleh informasi baru dan keterampilan, partisipasi dan kesempatan rekreasi, lingkungan fisik seperti polusi dan iklim serta transportasi menunjukkan peningkatan yang bermakna $(61,40 \pm 5,15$ vs $56,33 \pm 4,67)(\mathrm{p}<0,05)$. Hal ini kemungkinan disebabkan cara bermain angklung yang relatif mudah, karena meskipun hanya terdiri dari satu tangga nada, namun banyak saraf di otak lansia yang bisa diaktifkan misalnya, saraf motorik tangan saat lansia menggerakan angklung untuk membunyikan nada tertentu. Bersamaan dengan itu, saraf mata juga akan diaktifkan karena harus memperhatikan instruksi dari dirijen atau saat harus memperhatikan notasi dan teks lagu yang dinyanyikan. Ini sekaligus dapat memperbaiki gangguan verbal (ucapan) dan audio (pendengaran). Selain itu, karena melibatkan orang banyak satu tangga nada bisa dimainkan oleh beberapa orang. Bermain angklung sangat baik sebagai sarana untuk bersosialisasi dengan lingkungan keluarga dan masyarakat.

\section{SIMPULAN DAN SARAN}

Berdasarkan data penelitian dapat disimpulkan bahwa musik angklung dapat meningkatkan kualitas hidup wanita lansia pada domain fisik, psikologis, hubungan sosial, dan lingkungan. Hasil penelitian ini diharapkan dapat menjadi bahan informasi bahwa musik angklung dapat meningkatkan kualitas hidup wanita lansia di panti jompo dan sebaiknya di 
terapkan di seluruh unit lansia maupun panti jompo yang ada di Indonesia.

\section{DAFTAR PUSTAKA}

Arisanti. (2011). Rancangan Terapi Musik Angklung Untuk Menurunkan Penghayatan Perasaan Kesepian (Loneliness) Lansia Kasus Di Panti Werdha. Diunduh dari http://www.purtierplacenta.com/terapiasyik-untuk-stroke-bermain-angklung/

Ariani. (2012). Pengaruh Terapi Musik Angklung Terhadap Kesepian Pada Lansia Di Rumah Perlindungan Sosial Tresna Werdha Garut. Diunduh dari : http://jurnal.unpad.ac.id/ejournal/article/ view/869

Badan Perencanaan Pembangunan Nasional(BPPN), BPS, United Nations Population Fund. (2008) . Proyeksi penduduk Indonesia 2000-2025. Jakarta.: Bappenas, BPS,UNFPA.

Darmojo, R.B. (2006). Geriatri: ilmu kesehatan usia lanjut. Jakarta: Balai Penerbit Fakultas Kedokteran Universitas Indonesia.

Elvina. Perbedaan kualitas hidup lansia di rumah dan panti werdha. di akses melalui

https://lib.atmajaya.ac.id/default.aspx?ta $\mathrm{bID}=61 \& \mathrm{src}=\mathrm{k} \& \mathrm{id}=124555$

Edi Sucipto. (2010). Alat Musik Tradisional. Diunduh dari: http://www.alampedia.com/2014/09/ang klung-alat-musik-tradisional- khas.html

Fatimah. (2013). Perbedaan Kualitas Hidup Lanjut Usia yang Tinggal di Panti Jompo dengan yang Tinggal di Rumah di Kabupaten Tapanuli Selatan Tahun 2013. (Skripsi). Fakultas Ilmu Keperawatan, Universitas Sumatera Utara, Medan.

Fitria. (2011). Interaksi sosial dan Kualitas hidup Lansia di Panti Wredha UPT Pelayanan Sosial Lanjut Usia dan Anak Balita Binjai. (Skripsi,Universitas Sumatera Utara). Diunduh dari http://repository.usu.ac.id/downloads.ts wj.com/325251.pdf
Hillman C.H., Belopolsky,A.V., Snook,E.M., Kramer,A.F., McAuley,E. (2004) Physical activity and executive control: implications for increased cognitive health during older adulthood. Research quarterly for exercise and support. diunduh dari: http://www.pubmed.central.nih.gov.

Hutapea, Bonar.(2011). Emotional Intelegence dan Psychological Wellbeing pada Manusia Lanjut Usia Anggota Organisasi berbasis Keagamaan di Jakarta. INSAN,13( 02).

Karo, Waktu. (2010). Pengaruh Tingkat Pendapatan Terhadap Kualitas Hidup di Kelurahan Serdang Kecamatan Kemayoran Jakarta Pusat (Tesis). Universitas Indonesia. Diunduh dari http://www.lib.ui.ac.id/opac.pdf

Kusumoputro,S., Sidiarto,L.D., Samino. Munir,R., Nugroho,W.(2008). Kiat panjang umur dengan gerak dan latih otak. Jakarta: Penerbit Universitas Indonesia;

Nofitri. (2009). Gambaran Kualitas Hidup Penduduk Dewasa pada Lima Wilayah di Jakarta. (Skripsi). Universitas Indonesia, Jakarta.

Notoatmodjo. (2010). Metodologi penelitian kesehatan. Jakarta: Rineka Cipta.

Nugroho. (2008). Keperawatan gerontik dan geriatrik. Edisi 3. Jakarta: EGC.

Nursalam (2013). Metodologi penelitian ilmu keperawatan: Pendekatan Praktis Edisi 3. Jakarta: Salemba Medika.

Nurgianti. (2013). Pengaruh Senam Gerak dan Latih Otak Terhadap Demensia Pada Lansia Di Puskesmas Kecamatan Menteng Jakarta Pusat. (Skripsi, Universitas Muhammadiyah Jakarta). Diunduh dari http://www.library.psikumj.ac.id/index.php?p=show_detail\&id= $\underline{1981}$

Setyoadi., Noerhamdani., Ermawati. (2011). Perbedaan Tingkat Kualitas Hidup Pada Wanita Lansia Di Komunitas dan Panti. Jurnal Keperawatan, 2,2. Diunduh dari http://ejournal.umm.ac.id/index.php/kep erawatan/article/viewFile/621/641_mm scientific_journal.pdf. 
Sekarwiri, Edesia. (2008). Hubungan Antara Kualitas Hidup Dan Sense Of Community pada Warga DKI Jakarta yang Tinggal di Daerah Rawan Banjir. (Skripsi, Universitas Indonesia). Diunduh dari http://lib.ui.ac.id/125243362.2.pdf

Setiawan, Wungouw, Pangemanan. (2013). Pengaruh Senam Bugar Lanjut Usia Terhadap Kualitas Hidup Penderita Hipertensi. (Skripsi, Universitas Sam Ratulangi). Diunduh dari http://Jurnal.eBiomedik.pdf

Siregar, Arma, Lubis. (2013). Perbandingan Kualitas Hidup Lanjut Usia Yang Tinggal di Panti Jompo Dengan yang Tinggal di Rumah di Kabupaten Tapanuli Selatan. (Skripsi, Universitas Sumatra Utara). Diunduh dari http://repository.usu.ac.id/perbandingan kualitashidup.pdf

Sutikno, 2011. Hubungan Fungsi Keluarga Dengan Kualitas Hidup Lansia.

Setyoadi. (2002). Perbedaan Tingkat Kualitas Hidup pada Wanita Lansia di Komunitas dan Panti.ejournal UMM. Diunduh dari http://ejournal.umm.ac.id/index.php/kep erawatan/article/viewFile/621/641_mm_ scientific_journal.pdf.

Salamah.(2005). Kondisi Psikis Dan Alternatif Penanganan Masalah Kesejahteraan Sosial Lansi Di Panti Wredha. JurnalPKS, 11, 55 - 61.

Tambarkini. L. Jeklin. (2012). Latihan Fisik dan Kualitas Hidup. JKU, 1,1, Diunduh dari

http://www.igenursing.weebly.com/fix $\mathrm{j}$ ku ekin.pdf

WHO. (2004). The World Health Organization Quality of Life Introduction, Administration, Scoring and Generic Version Of The Assesment (WHOQOLBREF).

Yenni dan Hermawan. (2006). Pravalensi Penyakit Kronis dan Kualitas Hidup Pada Lanjut Usia. Diunduh dari http;//www.univmed.org/2012/04/yenni. pdf

Yulianti, et. all. (2014). Perbedaan Kualitas Hidup Lansia Yang Tinggal di Komunitas dengan di Pelayanan Sosial Lanjut Usia. Jurnal Unej 2(1). Diunduh dari

http;//www.jurnal.unej.ac.id/index.php/J PK/article/download/601/429 